\title{
Modelling and Optimization of Operational Setpoint Parameters for Maximum Fermentative Biohydrogen Production Using Box-Behnken Design
}

\author{
Patrick T. Sekoai \\ Sustainable Energy \& Environment Research Unit, School of Chemical and Metallurgical Engineering, \\ Faculty of Engineering and the Built Environment, University of the Witwatersrand, Private Bag 3, Wits, \\ Johannesburg 2050, South Africa; 679314@students.wits.ac.za; Tel.:+27-807-3783 \\ Academic Editors: Thaddeus Ezeji and Badal C. Saha \\ Received: 3 June 2016; Accepted: 15 July 2016; Published: 20 July 2016
}

\begin{abstract}
Fermentative biohydrogen production has been flagged as a future alternative energy source due to its various socio-economical benefits. Currently, its production is hindered by the low yield. In this work, modelling and optimization of fermentative biohydrogen producing operational setpoint conditions was carried out. A box-behnken design was used to generate twenty-nine batch experiments. The experimental data were used to produce a quadratic polynomial model which was subjected to analysis of variance (ANOVA) to evaluate its statistical significance. The quadratic polynomial model had a coefficient of determination $\left(R^{2}\right)$ of 0.7895 . The optimum setpoint obtained were potato-waste concentration $39.56 \mathrm{~g} / \mathrm{L}, \mathrm{pH} \mathrm{5.56}$, temperature $37.87^{\circ} \mathrm{C}$, and fermentation time $82.58 \mathrm{~h}$, predicting a biohydrogen production response of $537.5 \mathrm{~mL} \mathrm{H}_{2} / \mathrm{g}$ TVS. A validation experiment gave $603.5 \mathrm{~mL} \mathrm{H}_{2} / \mathrm{g}$ TVS resulting to a $12 \%$ increase. The $R^{2}$ was above 0.7 implying the model was adequate to navigate the optimization space. Therefore, these findings demonstrated the feasibility of conducting optimized biohydrogen fermentation processes using response surface methodology.
\end{abstract}

Keywords: biohydrogen production; modelling and optimization; box-behnken design

\section{Introduction}

The adverse effects of climate change coupled with environmental pollution makes it necessary to search for clean and sustainable energy resources [1-3]. Hydrogen is considered as one of the potential alternative fuels because it is a clean energy source and its combustion results in pure water. It can also be used in various applications such as fuel for automobiles, electricity, and thermal energy generation. Moreover, it can be derived from diverse substrates including waste materials.

Amongst the hydrogen producing methods, biological hydrogen production processes are highly recommended in hydrogen research fraternity as compared to thermo-chemical processes because they are environmentally friendly and less-energy intensive, i.e., can be carried out at ambient temperature and pressure. They mainly include photosynthetic and fermentative biohydrogen production. The challenges facing photosynthetic biohydrogen production are low production yields and the requirement for a light source. Meanwhile, fermentative biohydrogen production can produce hydrogen for long periods of time without any light using diverse substrates such as organic wastes and thus has a higher feasibility for industrialization. Moreso, it is more viable and extensively used [4]. Therefore, fermentative biohydrogen production process from waste materials plays a pivotal role because it simultaneously generates hydrogen while curbing environmental pollution.

The optimization of biohydrogen operational setpoint parameters is of critical importance in the research and development of biohydrogen fermentation technology owing to its impact on the 
economy and practicability of the process. The one dimensional search with successive variation in variables, such as the one-variable-at-a-time (OVAT) method, is still used, albeit it is well understood that it is impractical for the one dimensional search to achieve an appropriate optimum results in a restricted number of experiments [5]. The complexity of combinational interactions of operational setpoint variables and production does not allow for satisfactory detailed modelling [5]. Furthermore, single parameter optimization methods are not only tedious but can lead to misinterpretation of results, especially because the interaction between different factors is overlooked [6,7].

Statistical experimental approaches have been extensively used for many years and it can be implemented at various stages of an optimization strategy, such as screening of experiments or for investigating optimal setpoint parameters on production responses [8]. Fermentation optimization is conducted using a statistically designed experiment in a sequential process $[9,10]$. This involves a large number of variables that are initially screened and the irrelevant ones are eliminated in order to obtain a fewer and manageable set of parameters. The remaining variables are then optimized by a response surface modelling (RSM) method. Finally, after model building and optimization, the predicted optimum is verified [11,12]. The box-behnken RSM design uses a spherical design with good certainty within the design space. It requires fewer experiments as compared to other RSM designs [13]. In addition, box-behnken design is rotatable regardless of the number of parameters under investigation [14]. This statistical approach has been successfully applied in various fermentative biohydrogen production processes and has been proven to be very efficient in optimizing these processes [15-19].

This study modelled and optimized the operational setpoint parameters of potato-waste concentration, $\mathrm{pH}$, temperature, and fermentation time for maximum biohydrogen production process using box-behnken design. Moreover, the pairwise interactive effect of the above mentioned setpoint parameters was investigated on biohydrogen production response.

\section{Materials and Methods}

\subsection{Inoculum Development}

Biohydrogen-producing anaerobic mixed sludge was collected from Olifantvlei Wastewater Treatment Plant, Johannesburg, South Africa. The sludge was boiled at $100{ }^{\circ} \mathrm{C}$ for $30 \mathrm{~min}$. This was done in order to deactivate the biohydrogen-consuming methanogenic bacteria and enumerate the biohydrogen spore-forming bacteria. The sludge was supported with a nutrient stock solution (all in g/L): yeast extract 2.0, glucose 10, $\mathrm{K}_{2} \mathrm{HPO}_{4} 0.420, \mathrm{CaCl}_{2}$ 0.375, $\mathrm{MgSO}_{4} 0.312, \mathrm{NaHCO}_{3} 8.0$, $\mathrm{KCl} 0.25$. It was then transferred into an Erlenmeyer flask $(100 \mathrm{~mL})$ which was covered with foil, and cultured for three days at $\left(30^{\circ} \mathrm{C}\right)$ using a water-bath shaker, this was done to boost the population of biohydrogen-producing bacteria. In addition, the inoculum preparation stage is essential because biohydrogen-producing bacteria, such as Clostridium species, are fastidious and, therefore, a preliminary stage is carried out in order to revive them and increase their cell concentration. This served as inoculum for the twenty nine experimental designs.

\subsection{Experimental Design}

The four parameters studied and their search ranges were the concentration of potato-waste 10-40 g/L, pH 3-8, temperature 32-38 ${ }^{\circ} \mathrm{C}$, and fermentation time 5-120 h. Based on these, box-behnken design was used to generate 29 different experiments by varying the operational setpoint parameters, as shown in Table 1. 
Table 1. Biohydrogen production response from the box-behnken design.

\begin{tabular}{|c|c|c|c|c|c|}
\hline Run & PW & FT & $\mathrm{pH}$ & Temp & $\mathrm{H}_{2}$ Yield \\
\hline 1 & 10 & 62.5 & 8 & 35 & 89.8 \\
\hline 2 & 10 & 120 & 5.5 & 35 & 111.3 \\
\hline 3 & 25 & 5 & 3 & 35 & 0.5 \\
\hline 4 & 40 & 120 & 5.5 & 35 & 214.2 \\
\hline 5 & 40 & 5 & 5.5 & 35 & 30.9 \\
\hline 6 & 25 & 5 & 8 & 35 & 50.4 \\
\hline 7 & 25 & 120 & 8 & 35 & 58.6 \\
\hline 8 & 25 & 120 & 3 & 35 & 48.7 \\
\hline 9 & 10 & 5 & 5.5 & 35 & 10.5 \\
\hline 10 & 25 & 62.5 & 3 & 38 & 139.5 \\
\hline 11 & 25 & 120 & 5.5 & 38 & 405.0 \\
\hline 12 & 40 & 62.5 & 5.5 & 38 & 495.5 \\
\hline 13 & 25 & 5 & 5.5 & 38 & 0 \\
\hline 14 & 10 & 62.5 & 5.5 & 38 & 0 \\
\hline 15 & 25 & 62.5 & 8 & 38 & 528.0 \\
\hline 16 & 40 & 62.5 & 8 & 35 & 474.5 \\
\hline 17 & 25 & 62.5 & 5.5 & 35 & 373.0 \\
\hline 18 & 25 & 62.5 & 5.5 & 35 & 245.5 \\
\hline 19 & 25 & 62.5 & 5.5 & 35 & 333.0 \\
\hline 20 & 25 & 62.5 & 5.5 & 35 & 384.5 \\
\hline 21 & 10 & 62.5 & 3 & 35 & 0 \\
\hline 22 & 40 & 62.5 & 8 & 35 & 275.0 \\
\hline 23 & 25 & 62.5 & 5.5 & 35 & 432.5 \\
\hline 24 & 25 & 62.5 & 3 & 32 & 10.0 \\
\hline 25 & 25 & 5 & 5.5 & 32 & 0 \\
\hline 26 & 10 & 62.5 & 5.5 & 32 & 61.0 \\
\hline 27 & 25 & 62.5 & 8 & 32 & 310.0 \\
\hline 28 & 40 & 62.5 & 5.5 & 32 & 277.0 \\
\hline 29 & 25 & 120 & 5.5 & 32 & 0 \\
\hline
\end{tabular}

PW: Potato-waste concentration (g/L), FT: Fermentation time (h), Temp $\left({ }^{\circ} \mathrm{C}\right), \mathrm{H}_{2}$ yield $\left(\mathrm{mL} \mathrm{H}_{2} / \mathrm{g}\right.$ TVS).

\subsection{Substrates and Pretreatment}

Potato-waste was obtained from various dumping sites in the city of Johannesburg, South Africa. The effluents were oven dried at $60^{\circ} \mathrm{C}$ for $24 \mathrm{~h}$, and then grounded into fine particles $(0.2-0.5 \mathrm{~mm})$. The total volatile solid (TVS) of potato-waste was determined using Equation (1).

$$
\text { TVS }=\frac{\text { Weight of dried waste }- \text { Weight of ash }}{\text { Weight of dried waste }} \times 100 \%
$$

\subsection{Fermentation Process}

Substrate concentrations as specified in the design (Table 1) were weighed into $250 \mathrm{~mL}$ Erlenmeyer flask, and the volume was raised to $100 \mathrm{~mL}$ with distilled water. These were autoclaved prior to the fermentation process. One $\mathrm{ml}$ of inoculum was added to each $250 \mathrm{~mL}$ flask. The operational setpoint parameters were kept as specified in the design. The fermentation process was conducted in a temperature controlled shaking water-bath. Anaerobic microenvironments were achieved by flushing the fermenter flasks with nitrogen gas for $3 \mathrm{~min}$. The twenty-nine batch fermentation processes were carried out in duplicates.

\subsection{Analytical Procedures}

Hydrogen was measured and monitored using the hydrogen sensor at $1 \mathrm{~h}$ interval $\left(\mathrm{BCP}-\mathrm{H}_{2}\right.$ Bluesens $\mathrm{GmbH}$, Herten, Germany) connected to a computer measuring software system. The sensor has a measuring range of $0 \%-100 \%$ and use a thermal conductivity detector and infrared technology. The cumulative volume of hydrogen was calculated using Equation (2). 


$$
V_{\mathrm{H}, \mathrm{i}}=V_{\mathrm{H}, \mathrm{i}-1}+C_{\mathrm{H}, \mathrm{i}}\left(V_{\mathrm{G}, \mathrm{i}}-V_{\mathrm{G}, \mathrm{i}-1}\right)+V_{\mathrm{H}}\left(C_{\mathrm{H}, \mathrm{i}}-C_{\mathrm{H}, \mathrm{i}-1}\right)
$$

$V_{\mathrm{H}, \mathrm{i}}$ and $V_{\mathrm{H}, \mathrm{i}-1}$ are cumulative hydrogen gas volume at the current (i) and previous (i -1$)$ time intervals, $V_{\mathrm{G}, \mathrm{i}}$ and $V_{\mathrm{G}, \mathrm{i}-1}$ the total biogas volumes in the current and previous time intervals, $C_{\mathrm{H}, \mathrm{i}}$ and $C_{\mathrm{H}, \mathrm{i}-1}$ the fraction of hydrogen gas in the headspace of the reactor in the current and previous time intervals, and $V_{\mathrm{H}}$ the total volume of headspace in the reactor [20].

\subsection{General Model}

The results obtained from the experiments were used to develop a quadratic model that relates hydrogen production to the considered parameters. The general form of the model with four parameters is represented by Equation (3).

$$
\begin{aligned}
& Y=\alpha_{0}+\alpha_{1} x_{1}+\alpha_{2} x_{2}+\alpha_{3} x_{3}+\alpha_{4} x_{4}+\alpha_{11} x_{1}^{2}+\alpha_{22} x_{2}^{2}+\alpha_{33} x_{3}^{2}+\alpha_{44} x_{4}^{2}+\alpha_{12} x_{1} x_{2}+ \\
& \alpha_{13} x_{1} x_{3}+\alpha_{14} x_{1} x_{4}+\alpha_{23} x_{2} x_{3}+\alpha_{24} x_{2} x_{4}+\alpha_{34} x_{3} x_{4}
\end{aligned}
$$

where $Y$ is the biohydrogen production response, $\alpha_{0}$ is the regression coefficient, $\alpha_{1} x_{1}$ to $\alpha_{4} x_{4}$ are linear terms, $\alpha_{11} x_{1}^{2}$ to $\alpha_{44} x_{4}{ }^{2}$ are linear coefficient and $\alpha_{12} x_{1} x_{2}$ to $\alpha_{34} x_{3} x_{4}$ shows the interaction between parameters on biohydrogen production. The model fitness was evaluated by the analysis of variance (ANOVA) using Design Expert software (Stat Ease, Inc., Minneapolis, MN, USA).

\section{Results and Discussion}

\subsection{The Linear Interactive Effect of Parameters on Biohydrogen Production}

Table 1 shows the linear interaction of operational setpoint parameters on biohydrogen production. The hydrogen yields varied from 0 to $528 \mathrm{~mL} \mathrm{H}_{2} / \mathrm{g}$ TVS. The highest biohydrogen production yield was observed in runs 12 and 15, i.e., a maximum biohydrogen yield of 495.5 and $528.0 \mathrm{~mL} \mathrm{H}_{2}$ /g TVS, respectively, were obtained from these batch experiments. Analysis of individual parameters impact on the biohydrogen production pattern indicated that the fermentation times of 5 and $62.5 \mathrm{~h}$, low pH ( 3 and 5.5), and low concentration of potato waste (10 and $20 \mathrm{~g} / \mathrm{L})$ produce low yields of hydrogen. This is likely attributed to the low $\mathrm{pH}$ as confirmed in literature. $\mathrm{pH}$ has been identified as one of the most pivotal parameters that influence the growth of biohydrogen-producing bacteria. It also affects the activity of biohydrogen-producing hydrogenase enzymes and its metabolic pathway [4]. Moreover, it was shown that low $\mathrm{pH}$ values (below 4) have an inhibitory effect on the activity of biohydrogen-producing bacteria [4].

However, low fermentation time and high $\mathrm{pH}$, moderate temperature, and concentration of potato waste increases the hydrogen yield. Similar findings were reported by Sekoai and Gueguim Kana [4], hence this highlights the importance of operational setpoint parameters on biohydrogen production process modelling and optimization.

\subsection{Development of Model for Optimization of Biohydrogen Production}

\subsubsection{Model Analysis Based on Input Parameters}

The experimental data were used to generate a quadratic polynomial equation (Equation (4)). This mathematical model relates hydrogen production to $\mathrm{pH}$, temperature, fermentation time, and substrate concentration. Where $\mathrm{Y}$ represents the hydrogen production response; A, B, C, and D represents the operational setpoint parameters of potato-waste concentration, fermentation time, $\mathrm{pH}$, and temperature respectively. Moreover $\mathrm{A}^{2}, \mathrm{~B}^{2}, \mathrm{C}^{2}$, and $\mathrm{D}^{2}$ represents the quadratic coefficients of the above mentioned setpoint parameters.

$$
\begin{aligned}
& \mathrm{Y}=707.40+248.00 \mathrm{~A}+123.58 \mathrm{~B}+107.25 \mathrm{C}+152.00 \mathrm{D}+41.75 \mathrm{AB}-148.50 \mathrm{AC}+ \\
& 140.75 \mathrm{AD}-18.00 \mathrm{BC}+202.5 \mathrm{BD}+44.25 \mathrm{CD}-141.66 \mathrm{~A}^{2}-421.28 \mathrm{~B}^{2}-155.28 \mathrm{C}^{2}-96.66 \mathrm{D}^{2}
\end{aligned}
$$


The ANOVA was also conducted to test the significance and the fitness of the regression equation. Data from the analysis of variance is presented in Table 2, a high F-value (3.75) and low $p$-value (0.0094) indicates that the model is significant. The model's coefficients of estimates and their confidence intervals are presented in Table 3 . The generated model had a coefficient of determination $\left(R^{2}\right)$ value of 0.7895 , this implies that $78.95 \%$ of the data can be explained by the model. The results obtained from this study correlate with literature, it has been reported that $R^{2}$ values greater than 0.75 show that the model is accurate [21].

Table 2. Analysis of variance (ANOVA) of the box-behnken model.

\begin{tabular}{ccccccc}
\hline Source & SS & df & MS & F-Value & $p$-Value & $\boldsymbol{R}^{\mathbf{2}}$ \\
\hline Model & $2,890,000$ & 14 & 207,000 & 3.75 & 0.0094 & 0.7895 \\
A & 738,000 & 1 & 738,000 & 13.4 & 0.0026 & \\
B & 183,000 & 1 & 183,000 & 3.33 & 0.0895 & \\
C & 138,000 & 1 & 138,000 & 2.51 & 0.1357 & \\
D & 277,000 & 1 & 277,000 & 5.03 & 0.0415 & \\
AB & 6972.25 & 1 & 0.13 & 0.7273 & & \\
AC & 88,209 & 1 & 1.6 & 0.2263 & & \\
AD & $79,242.25$ & 1 & 1.44 & 0.2502 & & \\
BC & 1296 & 1 & 0.024 & 0.8803 & & \\
BD & 164,000 & 1 & 2.98 & 0.1064 & & \\
CD & 7832.25 & 1 & 7832.25 & 0.7117 & & \\
A & 130,000 & 1 & 2.36 & 0.1465 & & \\
B & $1,150,000$ & 1 & 20.9 & 0.0004 & & \\
C $^{2}$ & 156,000 & 1 & 2.84 & 0.1141 & & \\
$D^{2}$ & $60,602.16$ & 1 & 1.1 & 0.3119 & & \\
\hline
\end{tabular}

A: Potato-waste concentration, B: Fermentation time, C: $\mathrm{pH}, \mathrm{D}$ : Temperature, $\mathrm{AB}$ : interaction between potato-waste concentration and fermentation time, $\mathrm{AC}$ : interaction between potato-waste concentration and $\mathrm{pH}, \mathrm{AD}$ : interaction between potato-waste concentration and temperature, $\mathrm{BC}$ : interaction between fermentation time and $\mathrm{pH}$, $\mathrm{BD}$ : interaction between fermentation time and temperature, $\mathrm{CD}$ : interaction between $\mathrm{pH}$ and temperature, $\mathrm{A}^{2}$ : quadratic value for potato-waste concentration, $\mathrm{B}^{2}$ : quadratic value for fermentation time, $\mathrm{C}^{2}$ : quadratic value for $\mathrm{pH}, \mathrm{D}^{2}$ : quadratic value for temperature, SS: Sum of squares, MS: Mean of squares, df: degrees of freedom, $F$-value: Fisher-Snedecor distribution value, $p$-value: Probability value, $R^{2}$ : Coefficient of determination.

Table 3. Coefficients of estimates and their confidence intervals for box-behnken design.

\begin{tabular}{ccccccc}
\hline Factor & $\mathbf{C E}$ & $\mathbf{d f}$ & $\mathbf{S E}$ & $\mathbf{9 5 \%} \mathbf{C I L}$ & $\mathbf{9 5 \%} \mathbf{C I H}$ & $\mathbf{V I F}$ \\
\hline Intercept & 707.4 & 1 & 104.95 & 482.31 & 932.49 & \\
$\mathrm{~A}$ & 248 & 1 & 67.74 & 102.7 & 393.3 & 1 \\
$\mathrm{~B}$ & 123.58 & 1 & 67.74 & -21.71 & 268.88 & 1 \\
$\mathrm{C}$ & 107.25 & 1 & 67.74 & -38.05 & 252.55 & 1 \\
$\mathrm{D}$ & 152 & 1 & 67.74 & 6.7 & 297.3 & 1 \\
$\mathrm{AB}$ & 41.75 & 1 & 117.34 & -209.91 & 293.41 & 1 \\
$\mathrm{AC}$ & -148.5 & 1 & 117.34 & -400.16 & 103.16 & 1 \\
$\mathrm{AD}$ & 140.75 & 1 & 117.34 & -110.91 & 392.41 & 1 \\
$\mathrm{BC}$ & -18 & 1 & 117.34 & -269.66 & 233.66 & 1 \\
$\mathrm{BD}$ & 202.5 & 1 & 117.34 & -49.16 & 454.16 & 1 \\
$\mathrm{CD}$ & 44.25 & 1 & 117.34 & -207.41 & 295.91 & 1 \\
$\mathrm{~A}^{2}$ & -141.66 & 1 & 92.14 & -339.28 & 55.97 & 1.08 \\
$\mathrm{~B}^{2}$ & -421.28 & 1 & 92.14 & -618.91 & -223.66 & 1.08 \\
$\mathrm{C}^{2}$ & -155.28 & 1 & 92.14 & -352.91 & 42.34 & 1.08 \\
$\mathrm{D}^{2}$ & -96.66 & 1 & 92.14 & -294.28 & 100.97 & 1.08 \\
\hline
\end{tabular}

A: Potato-waste concentration, B: Fermentation time, $\mathrm{C}: \mathrm{pH}, \mathrm{D}$ : Temperature, AB: interaction between potato-waste concentration and fermentation time, $\mathrm{AC}$ : interaction between potato waste concentration and $\mathrm{pH}$, $\mathrm{AD}$ : interaction between potato-waste concentration and temperature, $\mathrm{BC}$ : interaction between fermentation time and $\mathrm{pH}, \mathrm{BD}$ : interaction between fermentation time and temperature, $\mathrm{CD}$ : interaction between $\mathrm{pH}$ and temperature, $\mathrm{A}^{2}$ : quadratic value for potato-waste concentration, $\mathrm{B}^{2}$ : quadratic value for fermentation time, $\mathrm{C}^{2}$ : quadratic value for $\mathrm{pH}, \mathrm{D}^{2}$ : quadratic value for temperature, $\mathrm{CE}$ : Coefficient of estimate, df: degrees of freedom, SE: Standard error, 95\% CIL: 95\% Confidence Intervals (Low limit), 95\% CIH: 95\% Confidence Intervals (High limit), VIF: Variance Inflation Factor. 


\subsubsection{Effect of Parameter Interaction on Biohydrogen Production Response}

The three dimensional response surface curves showing the production of biohydrogen as a function of parameters interaction are shown in Figures 1-6. The interactive effect of fermentation time and substrate concentration is illustrated in Figure 1; it was observed that an increase in fermentation time $(55-80 \mathrm{~h})$ and concentration of potato-waste (22-30 g/L) maximized the production of biohydrogen. It has been reported that an increase in substrate concentration enhances the activity of biohydrogen-producing bacterial species especially during their exponential growth phase [17]. This implies that a large-scale biohydrogen production process can be achieved within this range. Moreover, from these findings it can be deduced that increasing the concentration of potato-waste has a positive effect on biohydrogen production, but higher substrate concentration may have an inhibitory effect on its production $[17,22,23]$.

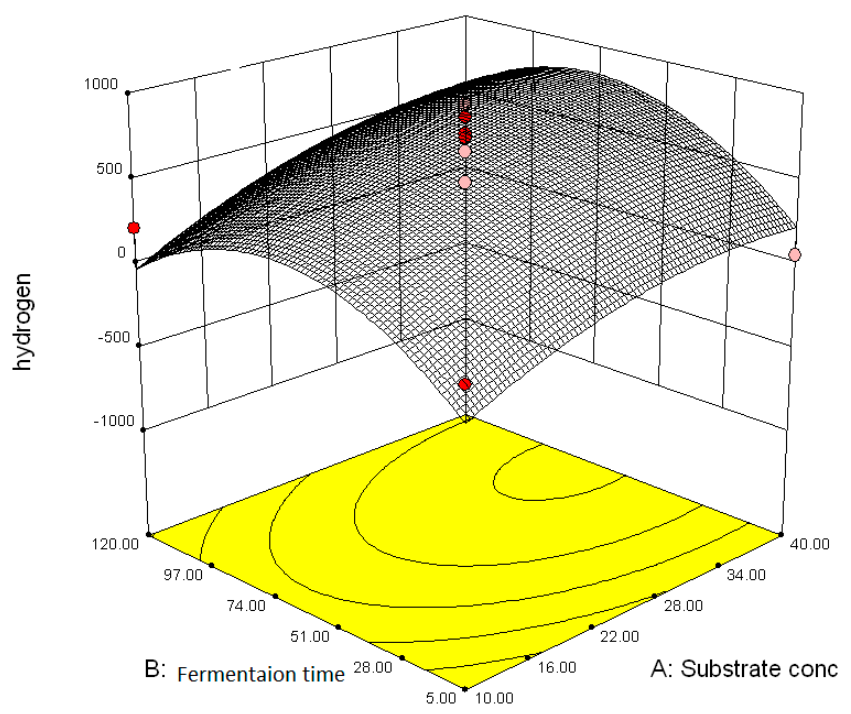

Figure 1. Response surface graph showing the interactive effect of fermentation time (h) and potato-waste concentration (conc, g/L) on hydrogen yield ( $\mathrm{mL} \mathrm{H}_{2} / \mathrm{g}$ TVS).

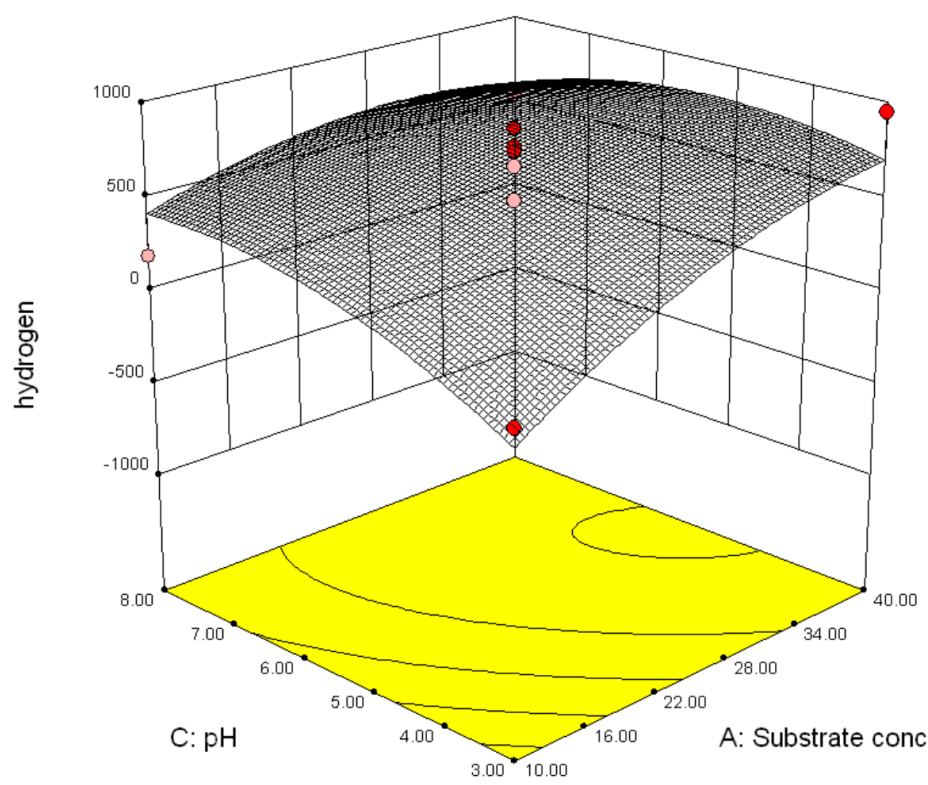

Figure 2. Response surface graph showing the interactive effect of $\mathrm{pH}$ and potato-waste concentration (conc, $\mathrm{g} / \mathrm{L}$ ) on hydrogen yield ( $\mathrm{mL} \mathrm{H}_{2} / \mathrm{g}$ TVS). 


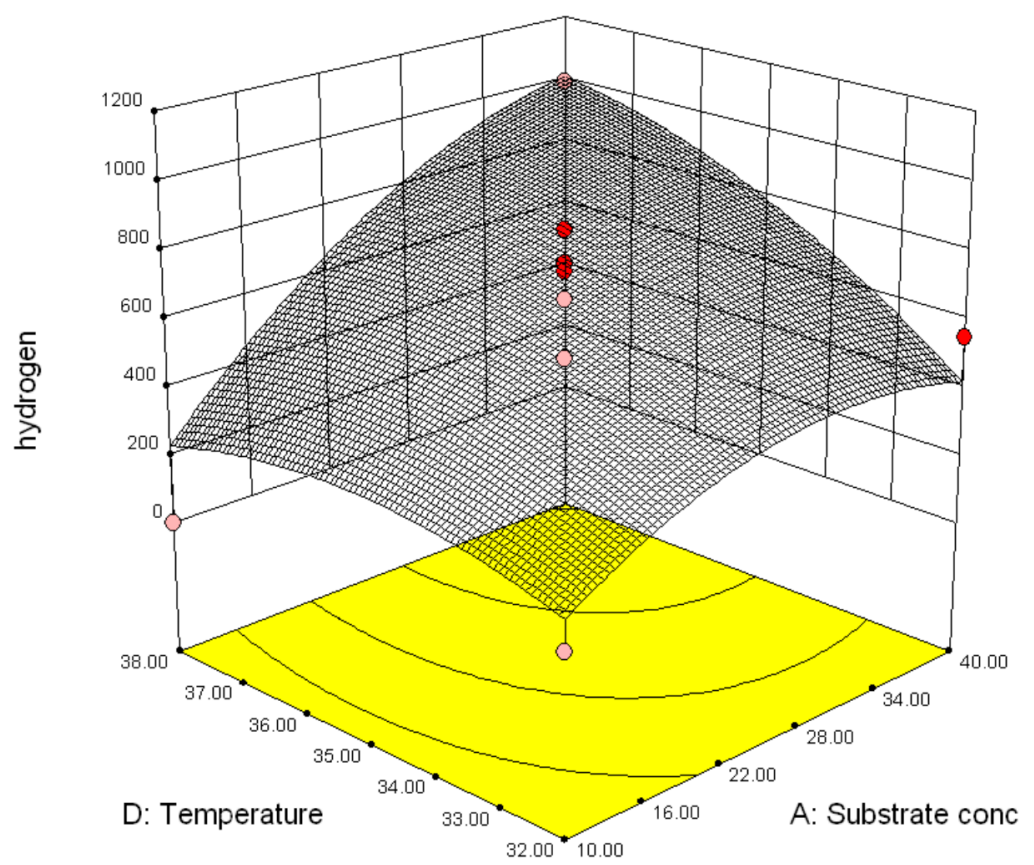

Figure 3. Response surface graph showing the interactive effect of temperature $\left({ }^{\circ} \mathrm{C}\right)$ and potato-waste concentration (conc, g/L) on hydrogen yield ( $\mathrm{mL} \mathrm{H}_{2} / \mathrm{g}$ TVS).

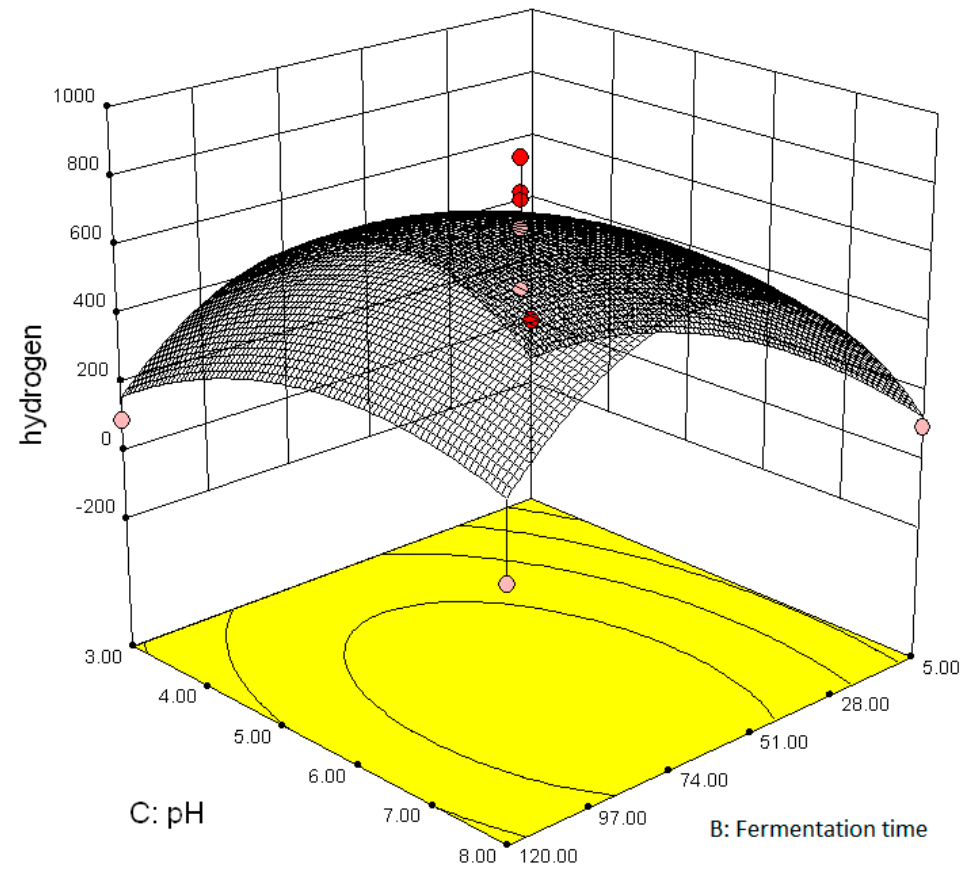

Figure 4. Response surface graph showing the interactive effect of fermentation time (h) and $\mathrm{pH}$ on hydrogen yield ( $\mathrm{mL} \mathrm{H}_{2}$ /g TVS). 


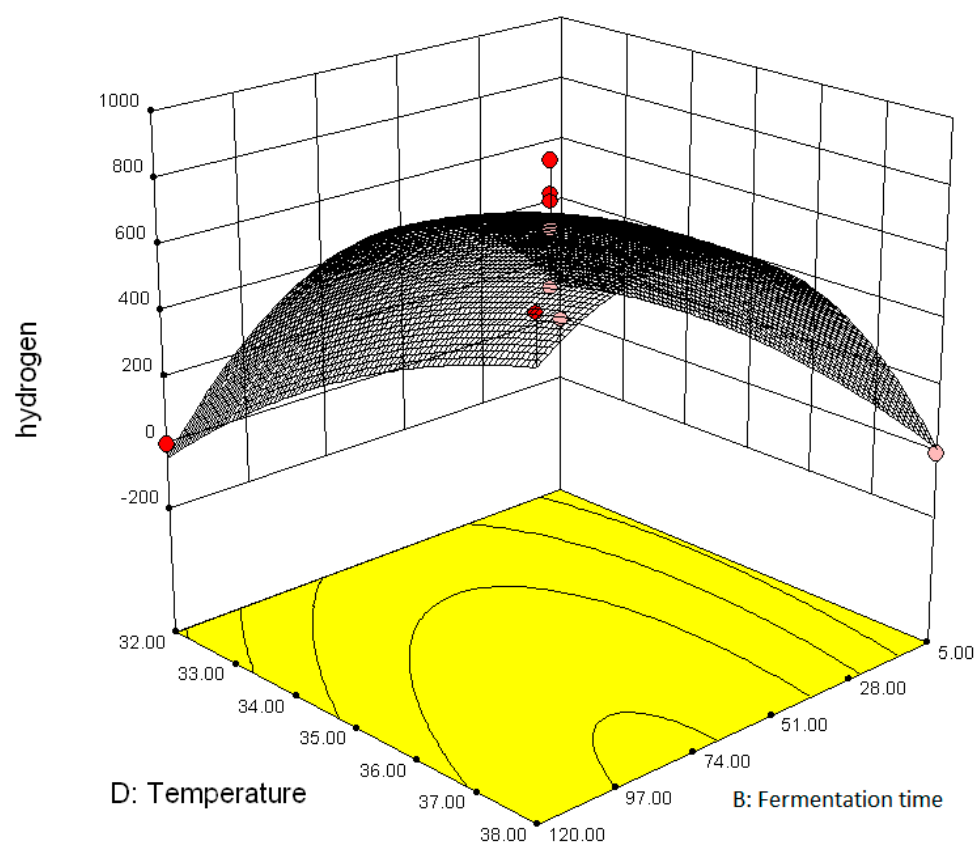

Figure 5. Response surface graph showing the interaction of fermentation time $(\mathrm{h})$ and temperature $\left({ }^{\circ} \mathrm{C}\right)$ on hydrogen yield ( $\mathrm{mL} \mathrm{H}_{2} / \mathrm{g}$ TVS).

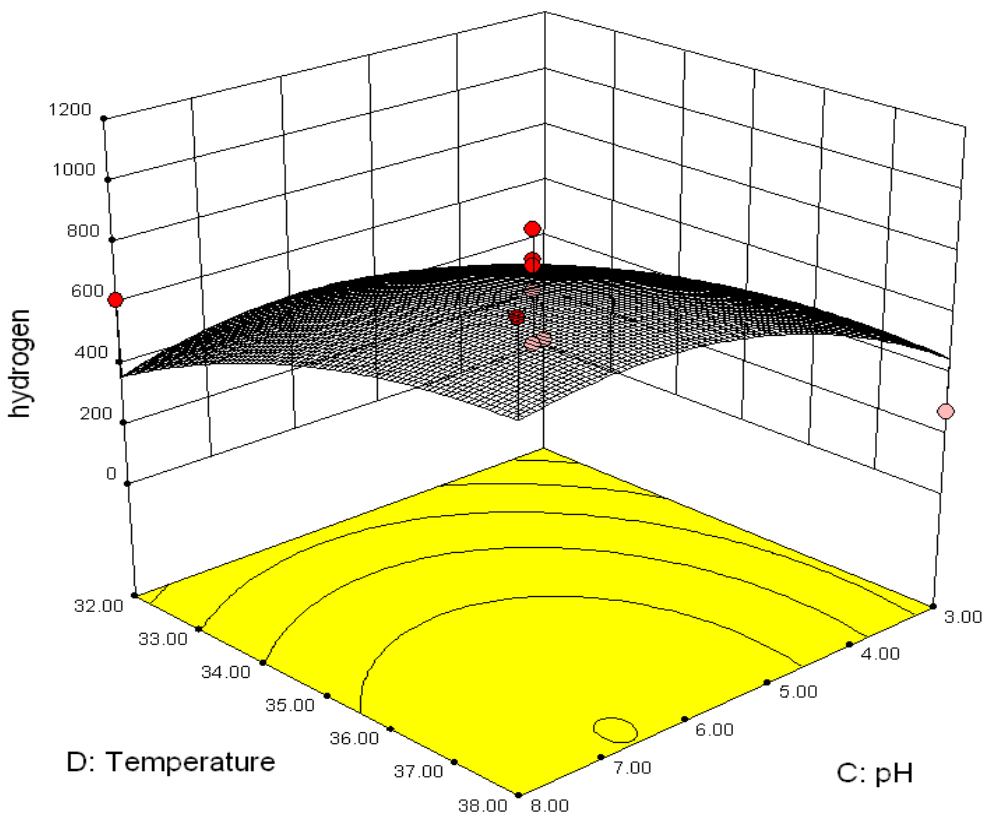

Figure 6. Response surface graph showing the interactive effect of temperature $\left({ }^{\circ} \mathrm{C}\right)$ and $\mathrm{pH}$ on hydrogen yield ( $\mathrm{mL} \mathrm{H}_{2}$ /g TVS).

The interaction between $\mathrm{pH}$ and potato-waste concentration is shown in Figure 2, a simultaneous increase in $\mathrm{pH}$ (above 5) and potato-waste concentration (above $22 \mathrm{~g} / \mathrm{L}$ ), increases biohydrogen production. It has been confirmed that at an appropriate range, increasing $\mathrm{pH}$ could potentially increase the metabolic activities of biohydrogen-producing bacteria during dark fermentative process, but extreme $\mathrm{pH}$ values may inhibit their metabolic pathways [24]. For instance, Sekoai and Gueguim Kana [4] reported an optimal $\mathrm{pH}$ value of 7.9. In contrast, low concentrations of potato-waste generate low yields of biohydrogen (Figure 2). It has also been confirmed in various studies of biohydrogen production that increasing substrate concentration within the experimental range 
enhances its production. Earlier studies by Mu et al. [25] and Wang et al. [26] reported optimal concentrations above $25.0 \mathrm{~g} / \mathrm{L}$ from organic effluents, whereas Sekoai and Gueguim Kana [19] reported an optimal concentration of $40.45 \mathrm{~g} / \mathrm{L}$ from organic fraction of solid municipal waste.

The synergistic effect of temperature and potato-waste concentration showed than an increase in both temperature $\left(35^{\circ} \mathrm{C}\right.$ ) and potato-waste concentration (above $22 \mathrm{~g} / \mathrm{L}$ ) resulted in maximum biohydrogen production (Figure 3). Several studies of biohydrogen fermentation process have shown that mesophilic and thermophilic temperature have the ability to increase the population of biohydrogen-producing bacteria; however some extreme temperatures may inhibit their metabolic activities as reported in literature [1]. An increase in potato-waste concentration enhanced the biohydrogen yield but the ability of biohydrogen-producing bacteria to produce hydrogen decreased rapidly with increasing potato-waste concentration from 100 to $300 \mathrm{~g} / \mathrm{L}$ (Figure 3). Thus, it is reasonable to predict that when the potato-waste concentration continues to increase to $520 \mathrm{~g} / \mathrm{L}$, the activity of biohydrogen-producing bacteria will be inhibited completely by the substrate at such high concentration, and the fermentative biohydrogen production by mixed cultures will stop accordingly [22]. With regards to the interactive effect of $\mathrm{pH}$ and fermentation time (Figure 4), it was observed that low $\mathrm{pH}$ (below 5) and short fermentation time (below $51 \mathrm{~h}$ ) minimizes the production of biohydrogen. Khanal et al. [27] indicated that low $\mathrm{pH}$ values of 4.0-4.5 cause longer lag periods. On the other hand, high initial $\mathrm{pH}$ values such as 9.0 decrease lag time, but have a lower yield of biohydrogen production [28]. An optimum retention time between 8.0 and $14 \mathrm{~h}$ was reported to yield maximum $\mathrm{H}_{2}$ without activating methanogenic process [29,30].

Considering the effect of temperature and fermentation time (Figure 5), decreasing both temperature (below $35^{\circ} \mathrm{C}$ ) and fermentation time (below $51 \mathrm{~h}$ ) generated low biohydrogen production. Similarly, Wang and Wan [1] observed that the concentration of hydrogen in batch tests increased with increasing temperature from 20 to $35^{\circ} \mathrm{C}$, however it decreased with further increase from 35 to $55^{\circ} \mathrm{C}$. A plausible explanation for such results might be due to the fact that the inoculum consisted of high population of mesophilic biohydrogen-producing bacteria. Conflicting results were reported by Hussy et al. [30]; they observed that reducing fermentation time from 18 to $12 \mathrm{~h}$ improved the biohydrogen yield without affecting starch removal efficiency when wheat starch was used as substrate. This might be attributed to various factors such as inoculum type, mode of fermentation, and operational setpoint parameters, i.e., organic loading rate.

In Figure 6, it is seen that low temperature (below $35^{\circ} \mathrm{C}$ ) coupled with low pH (below 5), decreases the overall production of biohydrogen. Therefore, temperature is one of the most critical parameters in biohydrogen process optimization because its affects the specific growth rate, substrate utilization rate, and the metabolic pathway of microorganisms [31-34]. $\mathrm{pH}$ is also highlighted as one of the most vital process parameters in biohydrogen production studies. It affects hydrogenase activity, metabolic activity, and substrate hydrolysis [35-37].

\subsection{Modelling and Optimization of Setpoint Parameters Using Box-Behnken Design}

Optimization studies revealed that a maximum hydrogen production of $537.5 \mathrm{~mL} \mathrm{H}_{2} / \mathrm{g}$ TVS can be obtained with potato-waste concentration of $39.56 \mathrm{~g} / \mathrm{L}$, fermentation time $82.58 \mathrm{~h}, \mathrm{pH} 5.56$, and temperature $37.87^{\circ} \mathrm{C}$. Model validation gave $603.5 \mathrm{~mL} \mathrm{H}_{2} / \mathrm{g}$ TVS resulting to a $12 \%$ increase. Thus, the models accurately optimized the biohydrogen production.

\section{Conclusions}

This study modelled and optimized the production of biohydrogen using box-behnken response surface methodology. It was shown that an enhanced biohydrogen production yield of $603.5 \mathrm{~mL}$ $\mathrm{H}_{2} / \mathrm{g}$ TVS is achievable at optimized operational setpoint variables of $39.56 \mathrm{~g} / \mathrm{L}, 82.58 \mathrm{~h}, 5.56$, and $37.87^{\circ} \mathrm{C}$ for substrate concentration, fermentation time, $\mathrm{pH}$, and temperature, respectively. Therefore, these findings could pave a way for large-scale biohydrogen production process by offering reliable fermentation data and, thus, make this technology economically viable. The scaling-up of biohydrogen 
production process will accelerate its commercialization and contribute in the global sustainable energy supply. Moreso, it is pivotal to conduct similar findings on large-scale processes to fully understand the process complexities of biohydrogen-producing fermentation processes from these setpoint conditions.

Acknowledgments: The Author would like to acknowledge financial support from the National Research Foundation (NRF-DST, grant no. 95061) and University of the Witwatersrand (Johannesburg, South Africa).

Author Contributions: Patrick T. Sekoai conducted the experimental design, and wrote the manuscript for publication.

Conflicts of Interest: The author declares no conflict of interest.

\section{References}

1. Wang, J.L.; Wan, W. Effect of temperature on fermentative hydrogen production by mixed cultures. Int. J. Hydrog. Energy 2008, 33, 5392-5397. [CrossRef]

2. Xing, D.F.; Ren, N.Q.; Wang, A.J.; Li, Q.B.; Feng, Y.J.; Ma, F. Continuous hydrogen production of auto-aggregative Ethanoligenens harbinense YUAN-3 under non-sterile condition. Int. J. Hydrog. Energy 2008, 33, 2137-2146. [CrossRef]

3. Yang, H.J.; Shen, J.Q. Effect of ferrous iron concentration on anaerobic bio-hydrogen production from soluble starch. Int. J. Hydrog. Energy 2006, 31, 2137-2146. [CrossRef]

4. Sekoai, P.T.; Gueguim Kana, E.B. Semi-pilot scale production of hydrogen from organic fraction of solid municipal waste and electricity generation from process effluents. Biomass Bioenergy 2014, 60, 156-163. [CrossRef]

5. Lotfy, W.; Ghanem, K.M.; Helow, E.R. Citric acid by a novel Aspergillus niger isolate: II. Optimization of process parameters through statistical experimental designs. Bioresour. Technol. 2007, 98, 3470-3477. [CrossRef] [PubMed]

6. He, G.Q.; Chen, Q.H.; Ju, X.J.; Shi, N.D. Improved elastase production by Bacillus sp. EL3140-further optimization and kinetics studies of culture medium for batch fermentation. J. Zhejiang Univ. Sci. 2004, 5, 149-156. [CrossRef] [PubMed]

7. Haltrich, D.; Preiss, M.; Steiner, W. Optimization of a culture medium for increased xylanase production by a wild strain of Schizophyllum commune. Enzyme Microbiol. Technol. 1993, 15, 854-860. [CrossRef]

8. Box, G.E.P.; Behnken, D.W. Some new three level designs for the study of quantitative variables. Technometrics 1960, 2, 455-475. [CrossRef]

9. Haaland, P.D. Experimental Design in Biotechnology; Marcel Dekker: New York, NY, USA, 1989.

10. Box, G.E.; Hunter, W.G.; Hunter, J.S. Statistical for Experimenters; John Wiley \& Sons: Hoboken, NJ, USA, 1978.

11. Strobel, R.J.; Nakatsukasa, W.M. Response surface for optimization Saccharopolyspora spinosa, a novel macrolide producer. J. Indian Microbiol. 1993, 11, 121-127. [CrossRef]

12. Swanson, T.R.; Carroll, J.O.; Britto, R.A.; Durhart, D.J. Development and field confirmation of a mathematical model for amyloglucosidase/pollulanase saccharafication. Starch 1986, 38, 382-387. [CrossRef]

13. Dhillon, G.S.; Brar, S.K.; Verma, M.; Tygi, R.D. Apple pomace ultrafiltration sludge-A novel substrate for fungal bioproduction of citric acid: Optimisation studies. Food Chem. 2011, 128, 864-871. [CrossRef]

14. Nath, K.; Muthukumar, M.; Kumar, A.; Das, D. Kinetics of two stage fermentation process for the production of hydrogen. Int. J. Hydrog. Energy 2008, 33, 1195-1203. [CrossRef]

15. Argun, H.; Kargi, F.; Kapdan, I.K.; Oztekin, R. Bio hydrogen production by dark fermentation of wheat powder solution: Effects of $\mathrm{C} / \mathrm{N}$ and $\mathrm{C} / \mathrm{P}$ ratio on hydrogen yield and formation rate. Int. J. Hydrog. Energy 2008, 33, 1813-1819. [CrossRef]

16. Rorke, D.; Gueguim Kana, E.B. Biohydrogen process development on waste sorghum (Sorghum bicolor) leaves: Optimization of saccharafication, hydrogen production and preliminary scale up. Int. J. Hydrog. Energy 2016, 41, 12941-12952. [CrossRef]

17. Mafuleka, S.; Gueguim Kana, E.B. Modelling and optimization of xylose and glucose production from Napier grass using hybrid pre-treatment techniques. Biomass Bioenergy 2015, 77, 200-208. [CrossRef]

18. O-Thong, S.; Prasertsan, P.; Intrasungkha, N.; Dhamwichukorn, S.; Birkeland, N.K. Optimization of simultaneous thermophilic fermentative hydrogen production and COD reduction from palm oil mill effluent by Thermoanaerobacterium-rich sludge. Int. J. Hydrog. Energy 2008, 33, 1221-1231. [CrossRef] 
19. Sekoai, P.T.; Gueguim Kana, E.B. A two-stage modelling and optimization of biohydrogen production from a mixture of agro-municipal waste. Int. J. Hydrog. Energy 2013, 38, 8657-8663. [CrossRef]

20. Chong, M.L.; Rahim, R.A.; Shirai, Y.; Hassan, M.A. Biohydrogen production by Clostridium butyricum EB6 from palm oil mill effluent. Int. J. Hydrog. Energy 2009, 34, 746-771. [CrossRef]

21. Myers, R.H.; Montgomery, D.C. Response Surface Methodology: Process and Product Optimization Using Designed Experiments; John Wiley \& Sons: Hoboken, NJ, USA, 1995.

22. Moodley, P.; Gueguim Kana, E.B. Optimization of xylose and glucose production from sugarcane leaves (Saccharum officinarum) using hybrid pretreatment techniques and assessment for hydrogen generation at semi-pilot scale. Int. J. Hydrog. Energy 2015, 40, 3859-3867. [CrossRef]

23. Wu, J.H.; Lin, C.Y. Biohydrogen production by mesophilic fermentation of food wastewater. Water Sci. Technol. 2004, 49, 223-228. [PubMed]

24. Sinha, P.; Pandey, A. An evaluative report and challenges for fermentative biohydrogen production. Int. J. Hydrog. Energy 2011, 36, 7460-7478. [CrossRef]

25. Mu, Y.; Wang, G.; Yu, H.Q. Response surface methodological analysis on bio hydrogen production by enriched anaerobic cultures. Enzyme Microbiol. Technol. 2006, 38, 905-913. [CrossRef]

26. Wang, G.; Mu, Y.; Yu, H.Q. Response surface analysis to evaluate the influence of $\mathrm{pH}$, temperature and substrate concentration on the acidogenesis of sucrose-rich wastewater. Biochem. Eng. J. 2005, 23, 175-184. [CrossRef]

27. Khanal, S.K.; Chen, W.H.; Li, L.; Sung, S. Biological hydrogen production: Effects of $\mathrm{pH}$ and intermediate products. Int. J. Hydrog. Energy 2004, 29, 1123-1131. [CrossRef]

28. Zhang, T.; Liu, H.; Fang, H.H.P. Biohydrogen production from starch in wastewater under thermophilic conditions. J. Environ. Manag. 2003, 69, 49-56. [CrossRef]

29. Chen, C.C.; Lin, C.Y.; Lin, M.C. Acid-base enrichment enhances anaerobic hydrogen production process. Appl. Microbiol. Biotechnol. 2002, 58, 224-228. [PubMed]

30. Hussy, I.; Hawkes, F.R.; Dinsdale, R.; Hawkes, D.L. Continuous fermentative hydrogen production from a wheat starch coproduct by mixed microflora. Biotechnol. Bioeng. 2003, 84, 619-629. [CrossRef] [PubMed]

31. Cheng, X.Y.; Liu, C.Z. Hydrogen production via thermophilic fermentation of cornstalk by Clostridium thermocellum. Energy Fuels 2011, 25, 1714-1720. [CrossRef]

32. Lay, J.J. Modelling and optimization of anaerobic digested sludge converting starch to hydrogen. Biotechnol. Bioeng. 2000, 68, 269-278. [CrossRef]

33. Li, C.L.; Fang, H.H.P. Fermentative hydrogen production from wastewater and solid wastes by mixed cultures. Crit. Rev. Environ. Sci. Technol. 2007, 37, 1-39. [CrossRef]

34. Van Ginkel, S.W.; Oh, S.E.; Logan, B.E. Bio hydrogen gas production from food processing and domestic wastewaters. Int. J. Hydrog. Energy 2005, 30, 1535-1542. [CrossRef]

35. De Gioannis, G.; Muntoni, A.; Polettini, A.; Pomi, R. A review of dark fermentative hydrogen production from biodegradable municipal waste fractions. Waste Manag. 2013, 33, 1345-1361. [CrossRef] [PubMed]

36. Sewsynker, Y.; Gueguim Kana, E.G. Modelling of biohydrogen generation in microbial electrolysis cells (MECs) using a committee of artificial neural networks (ANNs). Biotechnol. Biotechnol. Equip. 2015, 29, 1208-1215. [CrossRef]

37. Faloye, F.D.; Gueguim Kana, E.B.; Schmidt, S. Optimization of biohydrogen inoculum development via a hybrid $\mathrm{pH}$ and microwave treatment technique-Semi pilot scale production assessment. Int. J. Hydrog. Energy 2014, 39, 5607-5616. [CrossRef]

(C) 2016 by the author; licensee MDPI, Basel, Switzerland. This article is an open access article distributed under the terms and conditions of the Creative Commons Attribution (CC-BY) license (http://creativecommons.org/licenses/by/4.0/). 